\title{
PROPOSALS REGARDING A WEAPON REVIEW PROCESS IN SOUTH AFRICA (PART 1)
}

\author{
Ashley Charles Moorhouse \\ LLB \\ Advocate of the High Court of South Africa \\ Port Elizabeth
}

David Abrahams

BJuris LLB LLM LLM

Lecturer in Law

Nelson Mandela Metropolitan University

Port Elizabeth

\section{SUMMARY}

The purpose of this article is to put forward submissions regarding the implementation of a weapons review process in compliance of South Africa's obligations under Additional Protocol I (hereinafter "API") Article 36. Article 36 requires each state party to determine whether the employment of any new weapon, means or method of warfare that it studies, develops, acquires or adopts would, in some or all circumstances, be prohibited by international law. Article 36 does not specify how such a legal review should be implemented or conducted. Thus this article puts forward proposals regarding both the substantive and procedural aspects of a review of the legality of weapons, means and methods of warfare that the authors submit best befits the South African context.

A background regarding the legal limitations placed upon the use of certain weapons, means and methods of warfare and an explanation of South Africa's obligations regarding national implementation of a weapons review process, is given in paragraph 1 so as to create an understanding as to why it is necessary for the Republic of South Africa to implement a process to review the legality of weapons, means and methods of warfare.

Before the implementation of a weapons review process can be discussed, the subject matter of such a review must first be ascertained. Thus paragraph 2 contains a discussion regarding the definition of the term "weapons, means and methods of warfare" and a determination of which weapons shall form the subject matter of legal reviews. No specific manner of implementation is contained within API and thus it is at the discretion of the state in question, in this case South Africa, to adopt the necessary measures to implement this obligation. In this regard, paragraph 3 contains submissions regarding the status of the review body within the state hierarchy and its method of establishment. This paragraph also contains an explanation of the process by which South Africa acquires its weapons.

The legal scope of the review process is dealt with in paragraph 4 . Within this paragraph, the place of both treaty-based law and customary international law ("CIL") 
in the South African legal system is discussed. Furthermore, the treaty-law and customary international law rules binding upon South Africa regarding limitations of specific weapons and general weapons limitations are enumerated and the paragraph ends with a discussion of the Martens Clause.

\section{INTRODUCTION}

In order to understand why it is necessary for the Republic of South Africa to implement a process to review the legality of weapons, a background regarding the legal limitations placed upon the use of certain weapons, means and methods of warfare, is given below, as is an explanation of South Africa's obligations regarding national implementation of a weapons review process.

\section{Background to the limitation of the use of certain weapons, means and methods of warfare}

Modern warfare, with its rapid development of new weapons with enhanced firepower and lethality, has serious humanitarian repercussions. ${ }^{1}$ Access to increasingly sophisticated weapons is becoming easier. ${ }^{2}$ Fears exist regarding "the new and frightful weapons of destruction which are now at the disposal of the nations" and the spectre of future battles that "will only become more and more murderous" haunts the mind. ${ }^{3}$ To deal effectively with these possible humanitarian repercussions and to allay such fears, recourse must be had to international humanitarian law ("IHL"), which contains a body of rules that apply during armed conflict and that regulate the conduct of hostilities. ${ }^{4}$

The right of belligerents to choose their means and methods of warfare is not unlimited ${ }^{5}$ as $\mathrm{IHL}$ attempts to restrict or ban the use of certain weapons

1 Hogendoorn "The Human Rights Agenda: The Further Development of Arms Control Regimes" February 199934 Disarmament Diplomacy 5-9. See also 28th International Conference of the Red Cross and Red Crescent (Geneva, Switzerland, 2-6 December 2003) Agenda for Humanitarian Action (hereinafter "Agenda for Humanitarian Action") Final Goal 2.5; and Daoust, Coupland and Ishoey "New Wars, New Weapons? The Obligation of States to Assess the Legality of Means and Methods of Warfare" June 200284 IRRC 345354.

2 Daoust et al June 200284 IRRC 354.

3 See Dunant $A$ Memory of Solferino (Un Souvenir de Solferino, 1862) (1986) 128.

4 Lawand, Coupland and Herby A Guide to the Legal Review of New Weapons, Means and Methods of Warfare - Measures to Implement Article 36 of Additional Protocol I of 1977 (2006) 3 and 5; Lawand "Reviewing the Legality of New Weapons, Means and Methods of Wrfare" December 200688 IRRC 925 926; and ICRC Advisory Service on International Humanitarian Law "New Weapons" 2001 (hereinafter "ICRC Advisory Service") 1. See Durham and McCormack The Changing Face of Conflict and the Efficacy of International Humanitarian Law (1999) 66-73; Shepherd "A Bias-Free LOAC Approach Aimed at Instilling Battle Health in Our Airmen" 199437 The Air Force Law Review 25; and Kaszuba "Military Technology: Has It Changed The Rules of Warfare?" 1997 Research report submitted to the US Air War College, Air University (hereinafter "Kaszuba Research Report") 2.

5 See API Article 35.1; Part III, Section I and Part IV, Section I, Chapters I-IV; Hague Regulations 1907 Article 22 and CCW Convention Preamble par 3. See also Prohibition or Restriction of Certain Conventional Weapons Bill 2007 Preamble par 3; Legality of the 
in order to reduce the suffering inflicted by war. $^{6}$ As such, there are prohibitions and restrictions on specific weapons and general prohibitions and restrictions on weapons, means and methods of warfare. ${ }^{7}$ General prohibitions and restrictions encompass such principles as the prohibition on indiscriminate weapons ${ }^{8}$ and weapons which cause unnecessary and superfluous injuries, ${ }^{9}$ while prohibitions and restrictions on specific weapons comprise such weapons as biological and chemical weapons. ${ }^{10}$

Weapons limitations have ancient origins, ${ }^{11}$ with modern $\mathrm{IHL}$ being developed and codified over the last century and a half. ${ }^{12}$ Many of these modern rules regarding both general and specific prohibitions and restrictions on means and methods of warfare are considered part of CIL based on the widespread, representative and virtually uniform practice of states accepted as legal obligation and therefore mandatory for all parties to an armed conflict. ${ }^{13}$

Thus there exist humanitarian concerns regarding the rapid development of ever more lethal weapons and, simultaneously, there exists a body of rules that seeks to allay those concerns and regulate the development and use of certain weapons, means and methods of warfare. However, such rules cannot simply exist in abstracto. These rules need to be applied and a process must be formulated whereby weapons, means and methods of warfare are adjudged regarding compliance with these rules. Only then can weapons, means and methods of warfare be adequately and practically

Threat or Use of Nuclear Weapons Advisory Opinion of 8 July 1996, ICJ Reports 1996 (hereinafter "Nuclear Weapons AO") 78-79; Lawand December 200688 IRRC 925.

6 Hogendoorn February 199934 Disarmament Diplomacy 5-9; Lawand et al 3; ICRC Advisory Service 1; and "Report of the ICRC for the review conference of the 1980 UN conventions on Prohibitions or restrictions on the use of certain conventional weapons which may be deemed to be excessively injurious or to have indiscriminate effects" April 1994299 IRRC 123-182. See further St Petersburg Declaration Preamble par 1-5.

7 McClelland "The Review of Weapons in Accordance with Article 36 of Additional Protocol I" June 200385 IRRC 397; and Pictet The Principles of Humanitarian Law (1966).

8 See API Article 51-52; Nuclear Weapons AO 78; and St Petersburg Declaration.

9 See API Article 35.2. See also Nuclear Weapons AO 78-79; and Hague Regulations 1907 Article 23(e).

10 See Protocol for the Prohibition of the Use of Asphyxiating, Poisonous or Other Gases, and of Bacteriological Methods of Warfare 1925; and Convention on the Prohibition of the Development, Production and Stockpiling of Bacteriological (Biological) and Toxin Weapons and on their Destruction 1972. See also UN GA Resolution 2603(XXIV) of 16 December 1969.

$11 \mathrm{Eg}$, the principle that war should be waged using weapons not poison held by the Roman Senate; the condemnation of the use of poison by the Roman jurist Ulpian; the second Lateran Council's attempt, in 1139, at banning crossbows due to the more aggravated wounds it inflicted compared to the longbow and the Strasbourg Agreement of 1675 between France and the Holy Roman Empire created in response to the use of poisoned bullets. See Casagrande "Air Bombardment and the Law of Armed Conflict" Paper No. 10 1993 4; and Raičević "The History of Prohibition of the Use of Chemical Weapons in International Humanitarian Law" 20011 Law and Politics 613 615-616. See also Lawand et al 3; and Kaszuba Research Report 28. See further Grotius De lure Belli ac Pacis Libri Tres (1625) Book III Chapter 11 paragraph I-II and XIX

12 Lawand et al 3.

13 Lawand et al 3-4. See UN Sub-Commission on the Promotion and Protection of Human Rights Resolution 1996/16 of 29 August 1996. 
regulated so as to ensure that the aims of $\mathrm{IHL}$ are achieved in this regard. Thus the necessary tool of weapons review processes enters the discussion. ${ }^{14}$

\section{Obligations regarding national implementation of weapons review processes}

As regards the process of reviewing the legality of weapons, means and methods of warfare, the St Petersburg Declaration, adopted in 1868, was the first international instrument to refer to such a process:

"The Contracting or Acceding Parties reserve to themselves to come hereafter to an understanding whenever a precise proposition shall be drawn up in view of future improvements which science may effect in the armament of troops, in order to maintain the principles which they have established, and to conciliate the necessities of war with the laws of humanity."

API Article 36 contains the only other reference to such a process, stipulating that:

"[l]n the study, development, acquisition or adoption ${ }^{15}$ of a new weapon, means or method of warfare, a High Contracting Party is under an obligation to determine whether its employment would, in some or all circumstances, be prohibited by this Protocol or by any other rule of international law applicable to the High Contracting Party."

This wording makes it clear that states, party to API, are obligated to conduct weapons reviews, an obligation that applies equally whether the state in question develops and manufactures weapons itself or purchases them. ${ }^{16}$ Furthermore, it has been submitted that, although not required to do so by Article 36, states should review weapons to be exported as this is a logical extension of the obligation contained in API Article $1 .{ }^{17}$

South Africa, as a party to $\mathrm{API},{ }^{18}$ is bound thereto, both under international law ${ }^{19}$ and the Constitution. ${ }^{20}$ Owing to this binding effect, the obligation created by Article 36 and the legal maxim pacta sunt servanda, ${ }^{21}$

14 See Daoust "ICRC Expert Meeting on Legal Reviews of Weapons and the SIrUS Project" June 200183 IRRC 539; Daoust et al June 200284 IRRC 354; Agenda for Humanitarian Action Final Goal 2.5; Lawand December 200688 IRRC 930; and McClelland June 200385 IRRC 398.

15 Hereinafter the term "acquisition" will be used to cover the phrase "study, development, acquisition or adoption" and each term separately, unless otherwise stated.

16 Sandoz, Swinarski and Zimmermann Commentary on the Additional Protocols of 8 June 1977 to the Geneva Conventions of 12 August 1949 (1987) 426. See also ICRC Advisory Service 1. See further Vienna Convention on the Law of Treaties (hereinafter "VCLT") Article 31.

17 ICRC Advisory Service 1; and Daoust et al June 200284 IRRC 352.

18 Ratified in terms of API Article 93 on 21 November 1995.

19 VCLT Article 26.

20 S 231(5) of the Constitution of the Republic of South Africa, 1996 (hereinafter "the Constitution, 1996").

21 This principle places upon South Africa a general duty to perform the obligations stemming from API in good faith. VCLT Preamble and Article 26. See also Charter of the UN Preamble par 3. 
South Africa is required to implement measures at a national level, through the creation of new or the adaptation of existing internal procedures, for the purpose of reviewing weapons, means and methods of warfare in terms of international law in order to fulfill its obligation under Article $36 .^{22}$ It is submitted that the establishment of a formal, permanent procedure forms an integral part of such implementation. Such a procedure would necessitate the creation of a standing authority equipped to review the legality of weapons when they are being acquired. This procedure should be made mandatory and must be automatically activated at any time that South Africa is acquiring a new weapon. ${ }^{23}$

Although South Africa has not yet incorporated API into domestic law, ${ }^{24}$ resulting in API not having domestic effect as required by section 231(4) of the Constitution, ${ }^{25}$ this does not affect the binding force of this Protocol upon South Africa. ${ }^{26}$ Furthermore, this failure to implement API into domestic law cannot be invoked as a justification for non-performance of Article $36 .{ }^{27}$

In addition, states are under various international law obligations, both treaty-based and those based in CIL, that prohibit them from making use of unlawful weapons and military tactics. Thus it is submitted that the weapons review obligation created by Article 36 is an obligation placed upon all states within the international community, regardless of their relationship with $\mathrm{API},{ }^{28}$ as the application of these international law obligations regarding weapons, means and methods of warfare would necessitate such review processes as a means of ensuring compliance with these obligations. ${ }^{29}$ Additionally, such a review process would also satisfy the South African constitutional requirements that "national security must be pursued in compliance with the law, including international law"30 and further that "the security services must

22 Sandoz et al 1470 and 1482; and Daoust et al June 200284 IRRC 348. See also API Article 1.1 and 95.2; and Daoust June 200183 IRRC 540.

23 Lawand December 200688 IRRC 927.

24 The Geneva Conventions were published for "general information" in the Government Gazette in 1952 and 1968, but this does not constitute legislative incorporation. See GNs R749-752 in GGE 2064 of 1968-05-03; Dugard "Foreign Affairs and Public International Law" 1968 Annual Survey of South African Law 58 58-60. See also Dugard International Law - A South African Perspective 3ed (2005) 539.

25 Dugard 539.

26 VCLT Article 26.

27 VCLT Article 27. See also Treatment of Polish Nationals and Other Persons of Polish Origin or Speech in the Danzig Territory, PCIJ, 4 February 1932, Advisory Opinion, Series A/B, no.44 24; Free Zones of Upper Savoy and the District of Gex, PCIJ, 7 June 1932, Series A/B, no.46 167; Georges Pinson, French-Mexican Claim Commission, 9 October 1928, in RIAA, 5, 327-454 393-394 and Prosecutor v Blaskic (1996), ICTY, decision of the President, 3 April 1996, in ICTY, Judicial Reports, 1996 I, 773-793 7. See further Cassese International Law 2ed (2005) 217.

28 See Lawand et al 4. See also New weapons and the law, ICRC News 01/05 http://www.icrc.org/Web/Eng/siteeng0.nsf/iwpList74/E452B60D56294122C1256B66005F50 DD (accessed 2008-10-01); and Toth "So-Called Non-lethal Weapons in the Light of IHL" 20063 Miskolc Journal of International Law 22-40.

29 See Daoust et al June 2002 IRRC 347-348; Lawand et al 4; and Lawand December 200688 IRRC 925. See further ILC Draft Articles on Responsibility of States for Internationally Wrongful Acts 2001 Article 2.

30 S 198(c) of the Constitution, 1996. 
act, and must teach and require their members to act in accordance with the Constitution and the law, including customary international law and international agreements binding on the Republic". ${ }^{31}$

Whilst it is not specified how the determination of the legality of weapons, means and methods of warfare is to be enacted within the national sphere, it is clear that any body created for the purposes of weapons review must carry out such review taking into consideration the provisions of API and all other applicable international law rules. ${ }^{32}$ Furthermore, inter-state sharing of information on procedures adopted to comply with Article 36 would assist in the creation of such procedures in states without weapons review procedures. $^{33}$

The importance of the establishment and operation of weapons reviews on the basis of international law rules has been reiterated within the international community. ${ }^{34}$

It is a discussion of the legal review process required to comply with API Article 36 and the implementation of such a process into the Republic of South Africa that will form the content of this paper.

\section{SUBJECT MATTER OF THE REVIEW PROCESS}

\section{Introduction}

In order to discuss the national implementation of a weapons review process, its subject matter must first be determined. Thus a discussion of the definition of "weapons, means and methods of warfare" and which weapons are subject to review follows.

\footnotetext{
S 199(5) and s 200(2) of the Constitution, 1996.

API Article 36.

33 See API Article 84. See also Agenda for Humanitarian Action Action 2.5.3; Introductory Statement by Yves Sandoz at the Seminar on the Legal Review of New Weapons, Means and Methods of Warfare (Joigny-sur-Vevey, Switzerland, 14-16 June 2006) Official Statement 2006-06-16 (hereinafter "Introductory Statement by Yves Sandoz"); Lawand December 200688 IRRC 926; and Coupland and Herby "Review of the Legality of Weapons: A New Approach The SIrUS Project" September 1999835 IRRC 583-592.

34 See Final Declaration of the Second Review Conference of the States Parties to the Convention on Certain Conventional Weapons (Geneva, Switzerland, 11-21 December 2001) (CCW/CONF.II/2) 11; Final Document of the Third Review Conference of the States Parties to the Convention on Certain Conventional Weapons November 2006 par 14; the Plan of Action for the years 2000-2003 adopted by the 27th International Conference of the Red Cross and Red Crescent (Geneva, Switzerland, 31 October-6 November 1999) (hereinafter "Plan of Action 2000-2003") Section 21, Final Goal 1.5; Agenda for Humanitarian Action Final Goal 2.5; and Introductory Statement by Yves Sandoz. See also Daoust June 200183 IRRC 539.
} 


\section{Definition of "weapons, means and methods of warfare"}

Before a discussion of the types of weapons subject to review can be undertaken, the phrase "weapons, means and methods of warfare" must first be adequately defined.

"'Means of warfare' is a phrase referring to the tools of war, being weapons, whilst 'methods of warfare' refers to the ways in which weapons are used. ${ }^{35}$ it is unclear how the term 'weapon' differs from 'means of warfare'.

The term "weapon" has been interpreted in a number of forms for the purposes of weapons review, including:

- "an offensive or defensive instrument of combat used to destroy, injure, defeat or threaten. It includes weapon systems, munitions, sub-munitions, ammunition, targeting devices, and other damaging or injuring mechanisms;",

- "any type of weapon, weapon system, projectile, munition, powder or explosive, designed to put out of combat persons and/or materiel;";

- "any means of warfare, weapons systems/project, substance, etc. which is particularly suited for use in combat, including ammunition and similar functional parts of a weapon."

- "In the US, the phrase 'weapons or weapons systems' is used when describing what must be reviewed. ${ }^{40}$ Standard definitions have been proposed by the US DoD Law of War Working Group whereby the term 'weapon' is defined as referring to 'all arms, munitions, matériel, instruments, mechanisms, or devices that have an intended effect of injuring, damaging, destroying or disabling personnel or property ${ }^{41}$ and the term 'weapons system' refers to 'the weapon itself and those components required for its operation, including new, advanced or emerging technologies which may lead to development of weapons or weapons systems and which have significant legal and policy implications. Weapons systems are limited to those components or technologies having direct

35 See Lawand et al 3 fn 1; Daoust et al June 200284 IRRC 352; and ICRC Advisory Service 1. See also Meyrowitz "The Principle of Superfluous Injury and Unnecessary Suffering" March-April 1994299 IRRC 98103.

36 Daoust et al June 200284 IRRC 352 fn 19; and McClelland June 2003 (85) IRRC 404-405.

37 Legal Review of New Weapons Australian Department of Defence Instruction (General) OPS 44-1, 2 June 2005 (hereinafter "Australian Instruction") ss 3(a). See also McClelland June 200385 IRRC 404.

38 Défense, Etat-Major de la Défense, Ordre Général - J/836 (18 July 2002) (hereinafter "Belgian Order") ss 1(a).

39 Direktiv om folkerettslig vurdering av vapen, krigforingsmetoder og krigforingsvirkemidler, Ministry of Defence, 18 June 2003 (hereinafter "Norwegian Directive") ss 1.4.

40 See Legal Services: Review of Legality of Weapons under International Law, US Department of Army Regulation 27-53, 1 January 1979 (hereinafter "US Army Regulation"), ss 2(a); Implementation and Operation of the Defense Acquisition System and the Joint Capabilities Integration and Development System, US Department of Navy, Secretary of the Navy Instruction 5000.2C, 19 November 2004 (hereinafter "US Navy Instruction") 23, ss 2.6; and The Defense Acquisition System, US Department of Defense Directive 5000.1, 12 May 2003 (hereinafter "US Directive") ss E.1.1.15.

41 See also US Department of Air Force Instruction 51-402, Weapons Review, 13 May 1994 (implementing US Department of Air Force Policy Directive 51-4, Compliance with the Law of Armed Conflict, 26 April 1993; and US Department of Defense Directive 5100.77, DoD Law of War Program, 9 December 1998) (hereinafter "US Air Force Instruction"). 
injury or damaging effect on people or property (including all munitions and technologies such as projectiles, small arms, mines, explosives, and all other devices and technologies that are physically destructive or injury producing)'.

It can thus be deduced that the general interpretation of the phrase "weapons, means and methods of warfare" refers to all forms of weapons and weapons systems, including within its scope weapons of an antipersonnel, anti-matériel, lethal, non-lethal or less lethal nature. ${ }^{43}$ Furthermore, it has been submitted that the terms "means" and "methods of warfare" can be read together; thus including within the scope of the review equipment that does not constitute a weapon as such, but which nonetheless has a direct contribution on the offensive capability of the armed force which utilises it. ${ }^{44}$

Where uncertainty exists regarding whether a certain device is a weapon or not, it should be within the competence of the review body to decide upon the matter. ${ }^{45}$

The authors will be using the term "weapons" as an umbrella term for "weapons, means and methods of warfare", however, the terms "weapons, means and methods of warfare", "means and methods of warfare", "means of warfare" and "methods of warfare" will be used where required. In the South African military context, ${ }^{46}$ reference to "armaments" includes "weapons".

\section{Weapons subject to review}

The first step in a discussion of South Africa's proposed implementation of Article 36 is to determine which types of weapons are to be subjected to review.

The phrase "weapons, means or methods of warfare" has been held to include weapons in the widest sense and the ways in which they are used. ${ }^{47}$ The use of certain weapons may always be unlawful, no matter how it is that they are used. ${ }^{48}$ An example of such a weapon is poison, which is "unlawful in itself, as would be any weapon which would, by its very nature, be so imprecise that it would inevitably cause indiscriminate damage". ${ }^{49}$ However, the use of a weapon may be unlawful only under certain circumstances; thus the unlawfulness stems not from the weapon itself, but from the method in

42 See Hays Parks, Office of The Judge Advocate General of the Army, "Weapons Review Programme of the United States" presented at the Expert Meeting on Legal Reviews of Weapons and the SIrUS Project (Jongny sur Vevey, Switzerland, 29-31 January 2001) (hereinafter "Hays Parks Paper 2001").

43 See also Lawand et al 9; and ICRC Advisory Service 1. See further Daoust et al June 2002 84 IRRC 351, 352 fn 1 and 357-358; and Daoust June 200183 IRRC 540.

44 McClelland June 200385 IRRC 405.

45 Lawand et al 10 and 405-406.

46 See par 32 below.

47 Sandoz et al 1402. See Daoust et al June 842002 IRRC 351-352.

48 Sandoz et al 1402.

49 Ibid. 
which that weapon is used in those circumstances. ${ }^{50}$ An example of this is the use of precision-guided weapons to bomb a city under an indiscriminate targeting strategy.

Thus the material scope of a weapons review process under Article 36 would include all weapons and weapons systems, ${ }^{51}$ and the methods by which such weapons would be put to use under rules of engagement, operating procedures, tactics, military doctrine and countermeasures. ${ }^{52}$

Furthermore, such scope would also include all weapons to be acquired by a state, including both weapons acquired for further research and development on the basis of military specifications and those purchased "offthe-shelf" from outside manufacturers. ${ }^{53}$

Article 36 refers to "new weapons, means and methods of warfare". It has been submitted that usage of the term "new" is not to be interpreted in a strict, technical sense. ${ }^{54}$ Therefore, where an existing weapon is modified in a fashion that alters its function, it must subsequently undergo a new review, even if that weapon had previously passed a review prior to modification. ${ }^{55}$ Likewise, a weapon that a state is intending to acquire for the first time, without necessarily being a "new" weapon in a developmental or technological sense, would also need to undergo a review. ${ }^{56}$ Also, where a state has joined a new international treaty that may affect the legality of its existing weapons stocks, those weapons would need to be reviewed to establish their legality under those new legal obligations. ${ }^{57}$ Furthermore, those weapons already in service in South Africa prior to its ratification of API are not considered "new" weapons and thus do not need to be subjected to review. ${ }^{58}$ However, if any such weapons are subject to international scrutiny, it is submitted that those weapons should be reviewed. ${ }^{59}$

Ibid.

51 See par 22 above. See also Nuclear Weapons AO 86; Lawand et al 9; and Daoust et al June 200284 IRRC 351 and 355.

52 See Norwegian Directive subsection 1.4 and 2.4; Lawand et al 9; Daoust et al June 200284 IRRC 351 and 352 fn 1; and Lawand December 200688 IRRC 927-929. See further McClelland June 200385 IRRC 405-406.

53 Lawand et al 10; and Daoust et al June 200284 IRRC 355.

54 Sandoz et al 1472. See also Daoust et al June 200284 IRRC 352. See further Nuclear Weapons AO 86.

55 Daoust et al June 200284 IRRC 352 and 357; McClelland June 200385 IRRC 404; Australian Instruction $s 2$ and ss $3(\mathrm{~b})$ and fn 3 thereof; Belgian Order ss $5(\mathrm{i})$ and (j); Norwegian Directive ss 2.3; US Instruction ss 1.1.1-1.1.3 and US Army Regulation ss 6(a)(3). See also ICRC Advisory Service 1. See further US Department of the Air Force Memorandum for AAC/JAQ (Mr. Luthy) from AF/JA "Requested Legal Review of the Massive Ordnance Air Blast (MOAB) Weapon" 21 March 2003 (hereinafter "MOAB Review") 2.b.

56 Sandoz et al 1472; and McClelland June 200385 IRRC 404. See also Daoust et al June 200284 IRRC 352.

57 Lawand December 200688 IRRC 926. See also Sandoz et al 1472; and Norwegian Directive ss 2.2 and 2.6. See further US Instruction ss 1.1.3.

58 See Sandoz et al 1472.

59 McClelland June 200385 IRRC 404. See also Daoust June 200183 IRRC 358. 
A weapon's legality does not rest solely on its design or intended use, but also upon its expected manner of use during armed conflict. ${ }^{60} \mathrm{~A}$ state is only under the obligation to ascertain whether the employment of a weapon for its expected use would be prohibited under some or all circumstances. ${ }^{61}$ A state is not required to foresee or analyse all possible misuses of a weapon, for almost any weapon can be misused in a way that would be prohibited. ${ }^{62}$

\section{CREATION OF THE REVIEW PROCESS}

\section{Introduction}

As stated above, ${ }^{63}$ states are required to implement national measures so as to comply with their obligations under Article 36. As no specific manner of implementation is contained within API, it is at the discretion of the Republic to adopt the necessary measures to implement this obligation. ${ }^{64}$ Submissions regarding the hierarchical status and the method of establishment of the review process constitute this paragraph. Although the authors submit that the review body should not fall under the current Department of Defence (hereinafter "DoD") acquisition process, this process is elaborated upon in this paragraph so as to grant an understanding of the method by which South Africa acquires its weapons, an understanding that is vital to this paper as a whole.

\section{The South African Weapons Acquisition Process}

The Minister of Defence, Deputy Minister of Defence, the Secretary for Defence, the Chief of the SANDF, the Chief of Acquisitions and Procurement, the Chairperson and Chief Executive Officer of Armscor ${ }^{65}$ and the Armscor Board are all involved in the approval of armaments acquisition. ${ }^{66}$ The Department Acquisitions and Procurement Division (hereinafter "DAPD") is responsible for specialist acquisition management, ensures the acquisition of all equipment and services on behalf of the DoD, serves as the centralised control and execution of all acquisition activities within the DoD and is the process leader for the acquisition of all Category 1

60 See Additional Protocol 1 Article 36. See also Lawand et al 10; Lawand December 200688 IRRC 926; and McClelland June 200385 IRRC 406-407.

61 McClelland June 200385 IRRC 407; and Lawand et al 15.

62 Sandoz et al 1469. See Lawand December 200688 IRRC 926-929; and McClelland June 200385 IRRC 407. See further Doswald-Beck "International Humanitarian Law and the Advisory Opinion of the International Court of Justice on the Legality of the Threat or Use of Nuclear Weapons" 1997316 IRRC 35-55.

63 See par 13 above.

64 See ICRC Advisory Service 1; and Daoust June 200183 IRRC 540-541.

65 Armscor was established under Armaments Development and Production Act 57 of $1968 \mathrm{~s} 2$ (now repealed) and its existence is continued by Armaments Corporation of South Africa, Limited Act 51 of 2003 (hereinafter "Armscor Act") s 2(1).

66 White Paper on the South African Defence Related Industries December 1999 (hereinafter "SADRI White Paper"] Chapter 3. 
(Armaments) and Category 2 (Non-Armaments) items within the DoD. ${ }^{67}$ The responsibility for directing and co-ordinating all acquisition activities between the Arms of Service and Armscor lies with the Chief of Acquisitions. ${ }^{68}$ The Chief of Acquisitions reports to the Secretary for Defence. ${ }^{69}$

Although the DoD has overall responsibility for project teams and acquisition projects, all appointed project teams are under the joint control and supervision of the DAPD and Armscor ${ }^{70}$ Armscor is a statutory body ${ }^{71}$ that acquires defence matériel for the $\mathrm{DoD}^{72}$ and for any organ of state that may require such services. ${ }^{73}$ Armscor is focused on acquisition management and the management of certain strategic capabilities on behalf of the DoD through its subsidiary companies. ${ }^{74}$ Armscor's acquisition role can broadly be divided into system acquisition management, procurement management, product systems management and technology acquisition management. ${ }^{75} \mathrm{In}$ carrying out its objectives, Armscor must also meet the defence technology, research, development, analysis, test and evaluation requirements of the DoD. $^{76}$

Armscor is not a component of the DoD and may therefore not be a budget holder in terms of the Exchequer Act. ${ }^{77}$ The defence capital budget therefore resorts with the DAPD, which is accountable for the appropriate management of public monies and resources. ${ }^{78}$

Armscor, as the designated acquisition agency of the DoD, is responsible for professional programme management and the drafting, on behalf of the $\mathrm{DoD}$, of tender documentation for the contracting of industry during the execution of weapons acquisition programmes. ${ }^{79}$ Armscor ensures that contract management is in accordance with $\mathrm{DoD}$ requirements regarding technical, financial and legal integrity. ${ }^{80}$

Projects, depending on the size of the contract, are either approved by the Armaments Acquisition Council (AAC), the Armament Acquisition Steering

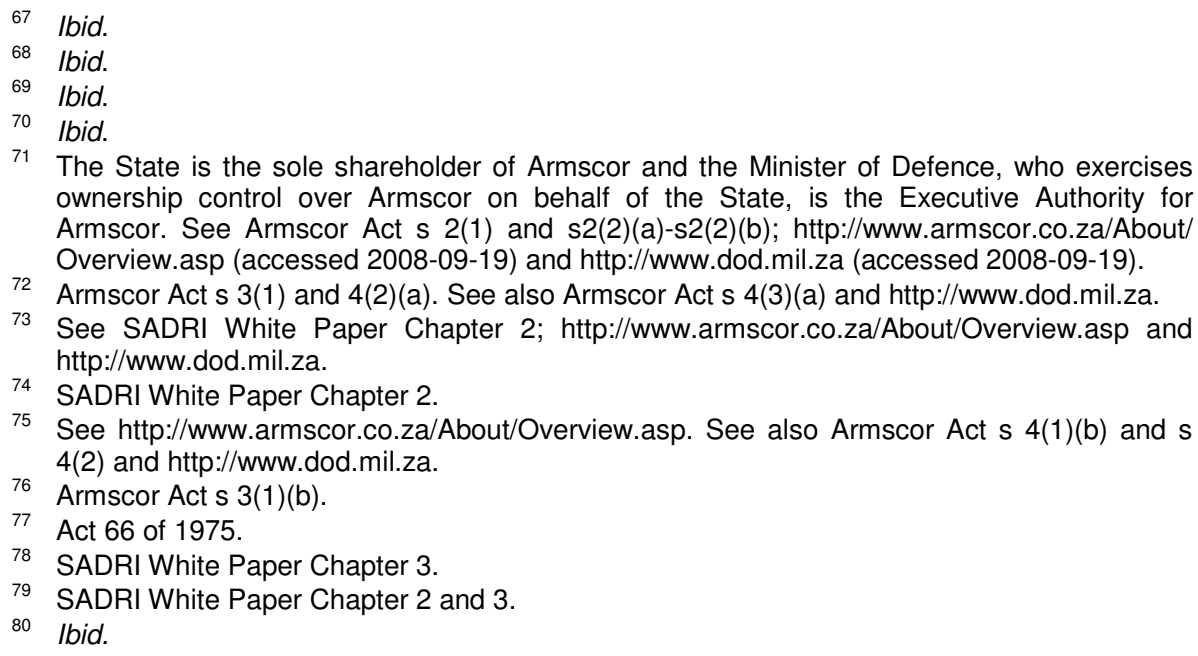

75 See http://www.armscor.co.za/About/Overview.asp. See also Armscor Act s 4(1)(b) and s 4(2) and http://www.dod.mil.za.

76 Armscor Act s 3(1)(b). 
Board (AASB) or the Armaments Acquisition Control Board (AACB).$^{81}$ These forums also select the contractors for approved projects. ${ }^{82}$

Upon completion of the approval and selection process, Armscor and DAPD places contracts on industry for project execution. ${ }^{83}$ Formal Contracts Authorisation Committees, the composition of which reflects appropriate representation of all relevant stakeholders, authorise all such contracts with respect to technical, financial, legal and contractor selection process integrity. ${ }^{84}$

The Armscor Board serves as a decision-making board for tender adjudication. ${ }^{85}$ It ensures that all contractual obligations of project management comply with national procurement legislation and are in the national interest. ${ }^{86}$

In order to ensure industrially cost-effective solutions for the DoD's requirements and local defence industry participation, organisations representing defence-related industries are involved in the acquisition process. ${ }^{87}$ Furthermore, all technical review teams incorporate, where appropriate, members from Armscor, the SANDF and the Defence Secretariat. $^{88}$

Other routine acquisition projects ${ }^{89}$ or programmes dealing with weapons systems and equipment which do not fall under the AAC, AACB, AASB or Defence Research and Development Board must secure Secretary for Defence approval and support before the awarding of contracts to successful suppliers of Armscor can occur. ${ }^{90}$ Adherence to the principle of a single nodal point between the DoD and Armscor through DAPD is observed. ${ }^{91}$

It is vital for the review body to understand this process and to call upon the bodies that form part of it for any reasonable assistance that is required.

\section{Position within the Hierarchy of the state}

Most of the states that have established weapons review processes have created them under the authority of their DoD. ${ }^{92}$ It has been submitted that

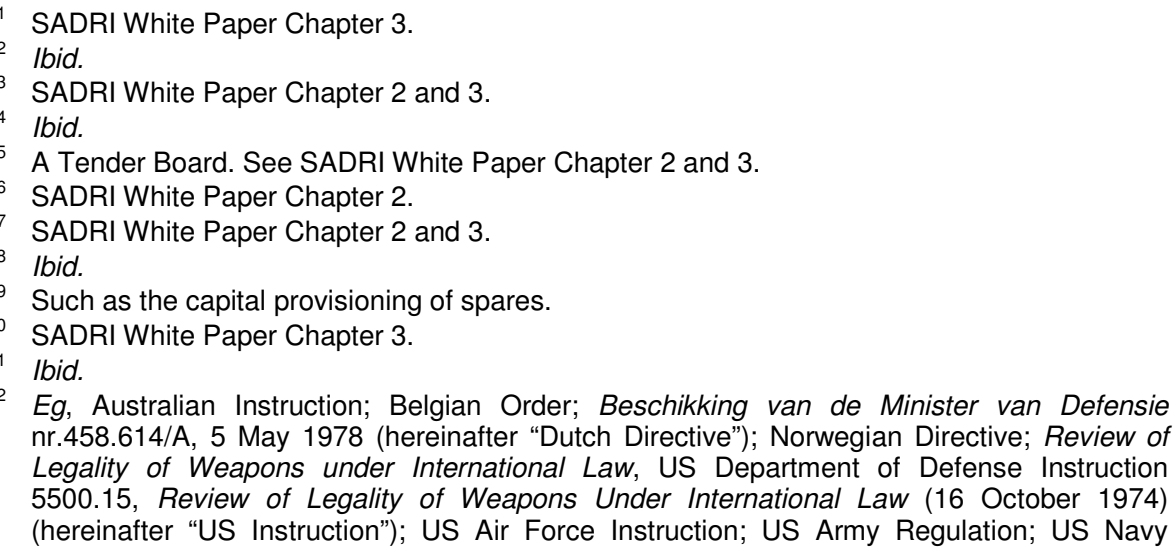

Eg, Australian Instruction; Belgian Order; Beschikking van de Minister van Defensie nr.458.614/A, 5 May 1978 (hereinafter "Dutch Directive"); Norwegian Directive; Review of Legality of Weapons under International Law, US Department of Defense Instruction 5500.15, Review of Legality of Weapons Under International Law (16 October 1974) (hereinafter "US Instruction"); US Air Force Instruction; US Army Regulation; US Navy 
this is advantageous as it is this Department that is responsible for the acquisition of weapons and the issuing weapons handling instructions. ${ }^{93}$ However, there has also been an approach of the review process being established by the government itself and implemented by an interdepartmental body. ${ }^{94}$ It has further been submitted that other relevant departments could establish the review process, such as the authority responsible for government procurement. ${ }^{95}$

In determining how to establish a weapons review body and where its place in the hierarchy of the state should be, careful consideration must take place to guarantee that the process operates independently and impartially and that its decisions are properly and firmly based upon the law and the necessary expert knowledge. ${ }^{96}$ It is only with these guarantees in place that a legitimate, authoritative review and the proper fulfilment of a state's obligation under Article 36 can take place.

It is submitted that the South African review process should not fall under the DoD and thus should not be placed within the acquisition process that has been elaborated upon above. ${ }^{97}$ It is submitted that an inter-departmental body would best preserve the independence and impartiality of the review and would ensure that the review did not fall solely under the influence of the DoD. Furthermore, an inter-departmental body would also guarantee that all the relevant experts from various departments would be represented.

All of these factors would add to the legitimacy of the review process and to the adequate fulfilment of the purpose of Article 36, being the guarantee that unlawful weapons and methods are not used in times of armed conflict. $^{98}$

\section{Method of establishment}

It has to be determined which method of establishment would be best suited within a South African legal and administrative framework.

Various states have created their review processes under delegated legislation issued from their respective DoDs. ${ }^{99}$ Sweden, however, established its inter-departmental review body under a government ordinance. ${ }^{100}$ As the author submits that the review body should be an inter-

Instruction; Policy for Non-Lethal Weapons, US Department of Defense Directive 3000.3, 9 July 1996 and US Directive. See also Daoust et al June 200284 IRRC 361.

93 Lawand et al 21.

94 Förordning om folkrättslig granskning av vapenproject, SFS 1994:536 s 8 (hereinafter "Swedish Ordinance").

95 Lawand et al 21.

96 Ibid.

97 See par 32 above.

98 Lawand et al 4; and ICRC Advisory Service 1.

99 Australian Instruction; Belgian Order; Dutch Directive; Norwegian Directive; US Instruction; US Air Force Instruction; US Army Regulation; US Navy Instruction; Policy for Non-Lethal Weapons, US Department of Defense Directive 3000.3, 9 July 1996; and US Directive.

100 Swedish Ordinance. 
departmental entity, this would necessitate the enactment of an Act of Parliament, as creation by delegated legislation would not be possible.

Past state practices in establishing review processes, regardless of the method, could still be of value in guiding the process of drafting the act of parliament that will establish a South African review body.

\section{LEGAL SCOPE OF THE REVIEW PROCESS}

\section{Introduction}

By obligating states to determine the lawfulness of weapons before they are acquired into a state's weapons stocks, Article 36 aims to ban the use of weapons that would inherently violate international law and to restrict the use of weapons that would violate international law only in certain circumstances. ${ }^{101}$

Therefore, the legal rules applicable to the review are those arising from the existing international law rules that bind South Africa. ${ }^{102}$ These international law rules are derived both from South Africa's treaty-based obligations and from $\mathrm{CIL}^{103}$ and must include general international law rules applicable to all weapons and international law rules prohibiting the use of specific weapons and/or restricting the methods whereby they can be used. Furthermore, the rules regarding weapons restrictions and prohibitions are submitted to be applicable in both international and non-international armed conflicts, due to it being held that "what is inhumane, and consequently proscribed, in international wars, cannot but be inhumane and inadmissible in civil strife". ${ }^{104}$

In the review process it must first be ascertained whether there exist specific international law rules binding upon the Republic prohibiting or restricting the use of the specific weapon under review. Where there are no such specific rules, the next step would be to determine whether the weapon under review and the expected methods by which it is to be used would conform with the general international law rules binding upon South Africa applicable to all weapons and methods of warfare.

In the absence of relevant specific and general binding international law rules, the review body must consider the legality of the weapon taking into account the principles of humanity and the dictates of public conscience. ${ }^{105}$

Furthermore, the review body would also have to take into account any UN resolutions regarding weapons prohibitions and restrictions. ${ }^{106}$ In

\footnotetext{
101 Sandoz et al 423-424; Daoust et al June 200284 IRRC 349; and Lawand et al 4. See ICRC Advisory Service 1-2.

102 Daoust et al June 200284 IRRC 347 and 349. See Daoust June 200183 IRRC 541.

${ }_{103}$ See API Article 36. See also Daoust et al June 200284 IRRC 349-350.

104 Prosecutor $v$ Tadic (Decision on the defence motion for Interlocutory Appeal on Jurisdiction), ICTY, Appeals Chamber, Decision of 2 October 1995119 and 127.

105 See par 46 below.
} 
addition, certain documents, such as the San Remo Manual on International Law Applicable to Armed Conflicts at Sea $1994^{107}$ and the Oxford Manual of the Laws of Naval War $1913,{ }^{108}$ could be considered by the review body, even though such documents are not binding upon South Africa. These two categories are not elaborated upon further in this paper.

It is submitted that the review body should be empowered to take cognisance of reasonably foreseeable future developments of the law. ${ }^{109}$ Such legal developments could occur with regard to both weapons currently in use, such as depleted uranium weaponry, cluster munitions and fuel-air explosives, ${ }^{110}$ and new weapons, such as acoustic weapons, nanotechnology and directed-energy weapons. ${ }^{11}$ This approach has the benefit of attempting to avoid the costly consequences of approving and acquiring a weapon, the use of which is likely to be restricted or prohibited in the near future.

${ }^{106}$ Eg, UN GA Resolution 1653(XVI) of 24 November 1961; UN GA Resolution 2936(XXVII) of 29 November 1972 and UN GA Resolution 38/75 of 15 December 1983.

107 Particularly Part IV thereof.

108 Particularly Section III thereof.

109 McClelland June 200385 IRRC 409-410; UK Ministry of Defence The Manual of the Law of Armed Conflict (2004) (hereinafter "UK Military Manual") 119 6.20.1; and Norwegian Directive ss 2.6. See April 1994 IRRC 123-182.

110 See UN Sub-Commission on the Promotion and Protection of Human Rights Resolution 1996/16 of August 1996 and Yeung Sik Yuen "Human Rights and Weapons of Mass Destruction, or with Indiscriminate Effect, or of a Nature to Cause Superfluous or Unnecessary Suffering" submitted to the UN Sub-Commission on the Promotion and Protection of Human Rights $44^{\text {th }}$ session in accordance with Sub-Commission resolution 2001/36 (E/CN.4/Sub.2/2002/38) (hereinafter "Yeung Sik Yuen Report") par 1, 100, 118, 133, 166-170. See also Meeting of Governmental Experts December 2002 (CCW/MSP/2002/CRP.1) par 21-22; and Report by the Secretary-General submitted to the UN Commission on Human Rights Sub-commission on Prevention of Discrimination and Protection of Minorities $49^{\text {th }}$ Session 24 June 1997 pursuant to Sub-commission resolution 1996/16 (E/CN.4/Sub.2/1997/27) par 1, 8, 11-12 and 23.

111 See Toth 2006 MJIL 22-40; Yeung Sik Yuen Report 175; and Lawand December 200688 IRRC 926. See also Wheelis and Dando "Neurobiology: A Case Study of the Imminent Militarization of Biology" September 200587 IRRC 553; Coupland and Loye "Legal and Health Issues: International Humanitarian Law and the Lethality or Non-lethality of Weapons" in Dando (ed) Non-Lethal Weapons: Technological and Operational Prospects (Jane's Special Report) (2000) 60-66; Fidler "The Meaning of Moscow: 'Non-lethal' Weapons and International Law in the Early 21st Century" 200587 IRRC 525 525; 1994 IRRC 123-182; Cook III, Fiely and McGowan "Nonlethal Weapons: Technologies, Legalities and Potential Policies" 19959 Airpower Journal (Special Edition) 77 85-86; and Kaszuba Research Report 11-12 and 19-20.

112 Lawand et al 11. 


\section{Treaty-based law}

As stated previously, ${ }^{113}$ international law dictates that South Africa is bound by all treaties to which it is a party. Moreover, the Republic is bound by all treaties that comply with the requirements of section 231 of the Constitution. These include treaties that complied with previous constitutions whilst they were operative. ${ }^{114}$

In addition, the Constitution states that "national security must be pursued in compliance with the law, including international law"115 and further that "the security services must act, and must teach and require their members to act, in accordance with the Constitution and the law, including customary international law and international agreements binding on the Republic."116 Thus South Africa must comply with its $\mathrm{IHL}$ treaty-based obligations regarding the legality of weapons.

Therefore, in implementing a legal review of weapons, those international instruments dealing with prohibitions and restrictions on the use of weapons to which the Republic is a party and which thereby bind the Republic must form part of the legal scope of the review, taking into account any reservations South Africa may have entered upon ratification of a treaty. ${ }^{118}$

\section{Customary international law}

Applicable CIL rules regarding prohibitions and restrictions upon means and methods of warfare need to be taken into account during the review process. It is accepted that CIL is binding upon all states within the international community. ${ }^{119}$ Furthermore, the South African common law regards CIL as part of South African domestic law, ${ }^{120}$ a position that is now entrenched within the Constitution. ${ }^{121}$

113 See par 13 above.

114 Including $282(1)$ (i) of the Constitution of the Republic of South Africa Act 200 of 1993; and s $6(2)$ (e) of the Republic of South Africa Constitution Act 110 of 1983. See s 231(5) of the Constitution, 1996.

${ }_{115} \mathrm{~S}$ 198(c) of the Constitution, 1996.

116 S 199(5) of the Constitution, 1996.

117 Strydom "Jus ad Bellum and Jus in Bello in the South African Constitution" 200429 SAYIL 78 88-89; and Dugard 539.

118 See McClelland June 200385 IRRC 406.

119 Cassese 157.

120 Dugard 55. See Grotius 16-18; Grotius Inleiding tot de Hollandsche Rechtsgeleertheyd en Aanmerkingen door S Groenewegen van der Made met Latynsche Aanteekeningen door W Schorer (1767) 1.2.10-13; Voet Commentarius ad Pandectas (1698) 1.1.18,19; Van der Linden Rechtsgeleerd Practicaal en Koopmans Handboek (1806) 4.2; Huber Heedendaagse Rechtsgeleertheyt soos elders, als in Frieslandt gebruikelijk (1686) 1.2.211.2.22; Van Bynkershoek "Quaestionum Juris Publici Libri Duo II" as translated in Brown Scott (ed) The Classics of International Law (1930) x1-x1i; Sanders "The Applicability of Customary International Law in Municipal Law - South Africa's Monist Tradition" 197740 THRHR 147 148; CC Maynard et alii v The Field Cornet of Pretoria 18941 SAR 214223 and 232; and Nduli v Minister of Justice 19781 SA 893 (A) 906B. See also South Atlantic Islands Development Corporation Ltd v Buchanan 19711 SA 234 (C) 238B-F and 283C-D; Ex parte Schumann 1940 NPD 251 254; Yorigami Maritime Construction Co Ltd v Nissho- 
Also the Constitution requires the Republic to comply with its CIL obligations under $\mathrm{IHL},{ }^{122}$ including those concerning the legality of weapons.

Thus CIL rules regarding prohibitions and restrictions upon weapons would be binding upon the Republic, regardless of its treaty obligations.

\section{Prohibitions and/or restrictions regarding specific weapons}

\section{Applicable treaty law}

The treaties regarding prohibitions and restrictions of specific weapons that would form part of the legal scope of a South African review process, these treaties having all been either signed and ratified, acceded to or accepted by the Republic, are listed below:

- Declaration (2) concerning Asphyxiating Gases 1899;

- Declaration (3) concerning the Prohibition of Using Bullets which Expand or Flatten Easily in the Human Body 1899;

- Hague Regulations 1907 Article 23(a);

- Convention (VIII) relative to the Laying of Automatic Submarine Contact Mines 1907;

- Treaty relating to the Use of Submarines and Noxious Gases in Warfare 1922 Article 5;

- Protocol for the Prohibition of the Use of Asphyxiating, Poisonous or Other Gases, and of Bacteriological Methods of Warfare 1925;

- Convention on the Prohibition of the Development, Production and Stockpiling of Bacteriological (Biological) and Toxin Weapons and on their Destruction 1972; ${ }^{123}$

Iwai Co Ltd 19774 SA 682 (C) 696E; Inter-Science Research and Development Services (Pty) Ltd v Republica Popular de Mocambique 19802 SA 111 (T) 124H; Kaffraria Property Co (Pty) Ltd v Government of the Republic of Zambia 19802 SA 709 (E) 712E-G; and Dugard 48-53. See further Ex parte Belli 1914 CPD 742 745-756; Marburger v The Minister of Finance 1918 CPD 183 187; (1) De Howorth v The SS 'India'; (2) Mann, George \& Co (Delalgoa) Ltd v The SS 'India' 1921 CPD 451 457-458; Crooks and Company v Agricultural Co-operative Union Ltd 1922 AD 423; Ex parte Sulman 1942 CPD 407; R v Lionda 1944 AD 348 352; and $S v$ Penrose 19661 SA 5 (N) 10.

121 S 232 of the Constitution, 1996. See also S v Basson 20051 SA 171 (CC) 216. See further s 233 of the Constitution, 1996; Dugard 56; Kaffraria Property Co (Pty) Ltd v Government of the Republic of Zambia supra 715; and Trendtex Trading Corporation v Central Bank of Nigeria [1977] QB 529 (CA) 554.

122 S 198(c) and S 199(5) of the Constitution, 1996. See also Strydom 2004 SAYIL 78 88-89 and Dugard 539.

123 The Non-Proliferation of Weapons of Mass Destruction Act 87 of 1993 is the enabling legislation regarding this Convention. See also GN under $s 13$ of the Non-Proliferation of Weapons of Mass Destruction Act 87 of 1993: Declaration of Certain Goods and Technologies to be Controlled and Control Measures Applicable to Such Goods. 
- CCW Convention 1980, and Amendment to Article $12001^{124}$ and its five Protocols:

- Protocol on Non-Detectable Fragments (Protocol I) $1980 ; ;^{125}$

- Protocol on Prohibitions or Restrictions on the Use of Mines, BoobyTraps and Other Devices 1980 as amended on 3 May 1996 (Protocol II to the 1980 Convention as amended on 3 May 1996); ${ }^{126}$

- Protocol on Prohibitions or Restrictions on the Use of Incendiary Weapons (Protocol III) 1980; ${ }^{127}$

- Protocol on Blinding Laser Weapons (Protocol IV) $1995 ;{ }^{128}$

- Protocol on Explosive Remnants of War (Protocol V) 2003;

- Convention on the Prohibition of the Development, Production, Stockpiling and Use of Chemical Weapons and on their Destruction 1993; ${ }^{129}$

- Convention on the Prohibition of the Use, Stockpiling, Production and Transfer of Anti-Personnel Mines and on their Destruction 1997; ${ }^{130}$

- African Nuclear Weapon-Free Zone Treaty 1995; and

- Rome Statute of the International Criminal Court $1998,{ }^{131}$ which includes in its definition of war crimes the employment of certain types of weapons during international armed conflict. ${ }^{132}$

The St Petersburg Declaration, the Convention on the Prohibition of Military or Any Hostile Use of Environmental Modification Techniques 1976 and the Protocol on Explosive Remnants of War (Protocol V) 2003 also contain rules regarding specific weapons. However, these treaties have not been signed and ratified, acceded to or accepted by South Africa and thus do not form part of the treaty-law binding South Africa in this regard. This notwithstanding, the provisions of such treaties should not be ignored. Certain provisions may be regarded as forming part of $\mathrm{ClL}$ and would thus be binding upon South Africa. Furthermore, international opinion and pressure regarding the provisions of these treaties may be such that it would be advisable for a South African review body to take them into account when

${ }^{124}$ See Prohibition or Restriction of Certain Conventional Weapons Bill 2007, which is the proposed South African enabling legislation for this Convention.

125 See s 5 of the Prohibition or Restriction of Certain Conventional Weapons Bill 2007.

${ }^{126}$ Subject to declarations in relation to Articles $1 ; 2.3$ and 5.2(b). See also s 6 of the Prohibition or Restriction of Certain Conventional Weapons Bill 2007.

127 See s 7 of the Prohibition or Restriction of Certain Conventional Weapons Bill 2007.

${ }^{128}$ Subject to a declaration in relation to Article 1. See also s 8 of the Prohibition or Restriction of Certain Conventional Weapons Bill 2007.

129 The Non-Proliferation of Weapons of Mass Destruction Act 87 of 1993 is the enabling legislation regarding this Convention.

130 Subject to a declaration of provisional application of Article 1.1 in accordance with Article 18 Implemented by Anti-Personnel Mines Prohibition Act 36 of 2003.

131 Implemented by Implementation of Rome Statute of the International Criminal Court Act 27 of 2002.

132 Rome Statute Article 8(2)(b)(xvii)-(xx). See also Implementation of Rome Statute Act 27 of 2002 Schedule 1 Part 3(b)(xvii)-(xx). 
determining the legality of a new weapon despite such rule not being legally binding upon the Republic.

During May 2008, South Africa was amongst the states that participated at the Diplomatic Conference for the Adoption of a Convention on Cluster Munitions in Dublin, Ireland. ${ }^{133}$ On 30 May 2008, the states at this conference formally endorsed the Convention on Cluster Munitions. ${ }^{134}$ This Convention was scheduled to be opened for signature on 3 December 2008 in Oslo, Norway. ${ }^{135}$ The Convention would enter into force on the first day of the sixth month after the month in which the 30th ratification had been deposited. ${ }^{136}$ Should South Africa have ratified this Convention, then the review body would have had to take this Convention into consideration once it entered force. It is submitted that if the situation arises where a review body is established prior to the ratification of said Convention, that the review body apply the provisions of the Convention to the review of weapons in anticipation of ratification.

\section{Applicable customary international law}

The CIL rules applicable to prohibitions and restrictions of specific weapons are contained in the list below:

- The prohibition on the use of poison or poisoned weapons; ${ }^{137}$

- the prohibition on the use of biological weapons; ${ }^{138}$

- the prohibition on the use of chemical weapons; ${ }^{139}$

- the prohibition on the use of riot-control agents as a method of warfare: $;^{140}$

- the prohibition on the use of herbicides as a method of warfare ${ }^{141}$ if they:

- "are of a nature to be prohibited chemical weapons;"

- "are of a nature to be prohibited biological weapons;"

- "are aimed at vegetation that is not a military objective;"

- "would cause incidental loss of civilian life, injury to civilians, damage to civilian objects, or a combination thereof, which may be expected to be excessive in relation to the concrete and direct military advantage anticipated; or"

- "would cause widespread, long-term and severe damage to the natural environment."

133 See Declaration of the Wellington Conference on Cluster Munitions 2008.

134 See http://www.clusterconvention.org (accessed 2008-08-22).

135 Ibid.

${ }^{136}$ Convention on Cluster Munitions 2008 Article 17.

137 Henckaerts and Doswald-Beck Customary International Humanitarian Law (2005) Vol I Rule 72251.

${ }^{138}$ Henckaerts and Doswald-Beck Rule 73256

139 Henckaerts and Doswald-Beck Rule 74259.

140 Henckaerts and Doswald-Beck Rule 75263.

141 Henckaerts and Doswald-Beck Rule 76265. 
- The prohibition on the use of bullets that expand or flatten easily within the human body; ${ }^{142}$

- the prohibition on the anti-personnel use of bullets that explode within the human body; ${ }^{143}$

- the prohibition on the use of weapons, the primary effect of which is to injure by fragments that are not detectable by $\mathrm{x}$-ray in the human body; ${ }^{144}$

- the prohibition on the use of booby-traps which are in any way attached to or associated with objects or persons entitled to special protection under $\mathrm{IHL}$ or with objects that are likely to attract civilians; ${ }^{145}$

- the obligation to take particular care to minimise the indiscriminate effects of landmines when such weapons are used and the obligation on a party to the conflict who has used landmines to remove or otherwise render them harmless to civilians, or facilitate their removal, at the end of active hostilities; ${ }^{146}$

- the obligation to take particular care to avoid, and in any event to minimise, incidental loss of civilian life, injury to civilians and damage to civilian objects where incendiary weapons are used. Furthermore, the anti-personnel use of incendiary weapons is prohibited, unless it is not feasible to use a less harmful weapon to render a person hors de combat ${ }^{147}$ and

- the prohibition on the use of laser weapons that are, as their sole combat function or as one of their combat functions, specifically designed to cause permanent blindness to un-enhanced vision. ${ }^{148}$

\section{General prohibitions and/or restrictions regarding weapons}

\section{Applicable treaty law}

Under API Article 36 states are obligated to consider the general prohibitions and restrictions on weapons as contained within the Protocol. ${ }^{149}$ Thus in conducting a review of the legality of weapons, the Republic is required to take into consideration the relevant provisions of API. ${ }^{150}$

142 Henckaerts and Doswald-Beck Rule 77268.

143 Henckaerts and Doswald-Beck Rule 78272.

144 Henckaerts and Doswald-Beck Rule 79275.

145 Henckaerts and Doswald-Beck Rule 80278.

${ }^{146}$ Henckaerts and Doswald-Beck Rule 81-83 280, 283, and 285.

147 Henckaerts and Doswald-Beck Rule 84-85 287 and 289.

${ }^{148}$ Henckaerts and Doswald-Beck Rule 86292.

149 See also Nuclear Weapons AO 78; and Daoust et al June 200284 IRRC 350.

150 These relevant provisions are API Article 35; $51.4 ; 51.5 ; 54 ; 55.1$ and 56 . See also API Article 48, 52 and 57; Nuclear Weapons AO 31; and Bouvier "Protection of the Natural Environment in Time of Armed Conflict" November-December 1991285 IRRC 567-578. 
Furthermore, all other treaties applicable to South Africa that contain general prohibitions or restrictions on weapons, means and methods of warfare must also be considered. ${ }^{151}$

\section{Applicable customary international law}

The applicable rules of CIL concerning general prohibitions and restrictions regarding weapons are enumerated below:

- The prohibition on the use of weapons that have an indiscriminate nature. ${ }^{152}$ Under this prohibition is included means of warfare that cannot be directed at a specific military objective and the effects of which cannot be limited as required by $\mathrm{IHL} ;{ }^{153}$

- the prohibition on bombardment attacks of any methods or means which treats as a single military objective a number of clearly separated and distinct military objectives located in a city, town, village or other area containing a similar concentration of civilians or civilian objects, ${ }^{154}$

- the prohibition on the launching of an attack which may be expected to cause incidental loss of civilian life, injury to civilians, damage to civilian objects, or a combination thereof, which would be excessive in relation to the concrete and direct military advantage anticipated. ${ }^{155}$ This is commonly known as the proportionality rule;

- the prohibition on the use of methods or means of warfare that are intended, or may be expected, to cause widespread, long-term and severe damage to the natural environment. ${ }^{156}$ Furthermore, the destruction of the natural environment may not be used as a weapon; ${ }^{157}$ and

- the prohibition on the use of methods or means of warfare that are of a nature to cause superfluous injury or unnecessary suffering. ${ }^{158}$

151 Eg, Hague Regulations 1907 Article 23(e) and Rome Statute Article 2(b)(iv).

152 Henckaerts and Doswald-Beck Rule 71 244. See also Henckaerts and Doswald-Beck Rule 11 37. See further Nuclear Weapons AO 78, Declaration of Mr Bedjaoui, President 20 and Dissenting Opinion of Judge Higgins 24; Prosecutor $v$ Strugar and others (Decision on Defence preliminary motion challenging jurisdiction), ICTY, Trial Chamber, decision of 7 June 2002 18-21; Cassese 416; Final Report to the Prosecutor by the Committee Established to Review the NATO Bombing Campaign Against the Federal Republic of Yugoslavia 55; and Doswald-Beck 1997 IRRC 35-55.

153 Henckaerts and Doswald-Beck Rule 1240.

154 Henckaerts and Doswald-Beck Rule 1343.

155 Henckaerts and Doswald-Beck Rule 1446.

156 Henckaerts and Doswald-Beck Rule 45 151; and Nuclear Weapons AO $32-33$ and 35. See also Henckaerts and Doswald-Beck Rule 44147.

157 Henckaerts and Doswald-Beck Rule 45 151. See also Nuclear Weapons AO 32 and UN GA Resolution 47/37 of 25 November 1992.

158 Henckaerts and Doswald-Beck Rule 45 151. See also International Military Tribunal, Trial of the Major War Criminals, 14 November 1945-1 October 1946, 1947, Vol 1, 254; and Henckaerts and Doswald-Beck Rule 70 237. See further Prohibition or Restriction of Certain Conventional Weapons Bill 2007 Preamble par 4-5; Nuclear Weapons AO 78-79, 92 and 95, Separate Opinion of Judge Fleischhauer 2, Dissenting Opinion of Judge Higgins 12 and 24 and Declaration by Judge Herczegh 2; CCW Convention Preamble paragraph 3; Hunger "The Convention on Certain Conventional Weapons Or, How to Reduce Human Suffering or 


\section{Martens Clause}

Originally put into the preamble to the 1899 Hague Convention, ${ }^{159}$ the Martens Clause ${ }^{160}$ states that if a particular rule is not to be found in treaty law nor CIL, civilians and combatants remain "under the protection and authority of the principles of international law derived from established custom, from the principles of humanity and from the dictates of public conscience". ${ }^{161}$ It has been held that the Martens Clause forms part of CIL. ${ }^{162}$ Whilst it has been debated whether the "principles of humanity" and the "dictates of the public conscience" are separate, legally-binding yardsticks against which a weapon can be measured in law or whether they are rather moral guidelines, ${ }^{163}$ the ICJ affirmed the importance of the Martens Clause, "whose continuing existence and applicability is not to be doubted", ${ }^{164}$ and stated that it "has proved to be an effective means of addressing the rapid evolution of military technology". ${ }^{165}$ Thus the basic principles of humanitarian law continue to apply to all new weapons and it has been held that no state disputes this fact.

It has further been held that the Martens Clause was not limited to affirming $\mathrm{CIL}$, but rather provided the authority for treating the principles of humanity and the dictates of the public conscience as principles of international law to be ascertained in the light of changing circumstances. ${ }^{167}$ Furthermore, it has been held to be "a general clause, making the usages established among civilized nations, the laws of humanity and the dictates of the public conscience into the legal yardstick to be applied if and when the specific provisions" of treaty law do not cover specific situations. ${ }^{168}$

Restricting the Use of Certain Conventional Weapons" March 2003 (II) Strategic Insights; Hogendoorn February 199934 Disarmament Diplomacy 5-9; and Doswald-Beck 1997 IRRC 35-55.

159 Convention (II) with Respect to the Laws and Customs of War on Land and its annex: Regulations concerning the Laws and Customs of War on Land 1899 Preamble par 9.

160 See also Hague Regulations 1907 Preamble paragraph 8; API Article 1.2 and APII Preamble par 3.

161 API Article 1.2. See also Nuclear Weapons AO Dissenting Opinion of Judge Weeramantry 483-484; Doswald-Beck 1997 IRRC 35-55; and Daoust et al June 200284 IRRC 351. See further Cassese 160-161; and League of Nations. Permanent Council of International Justice, Advisory Committee of Jurists Proces-verbaux of the Proceedings of the Committee 16 June-24 July 1920 286-339.

162 Nuclear Weapons AO 84 and 87.

163 See Blinding Weapons: Reports of the Meetings of Experts convened by the International Committee of the Red Cross on Battlefield Laser Weapons, 1989-1991 (1993) 340-341 and 344-346; and Cassese "The Martens Clause: Half a Loaf or Simply Pie in the Sky" 200011 EJIL 187. See also Doswald-Beck 1997 IRRC 35-55.

${ }_{164}$ Nuclear Weapons AO 87. See also Doswald-Beck 1997 IRRC 35-55.

165 Ibid.

166 See Nuclear Weapons AO 86. See also Doswald-Beck 1997 IRRC 35-55; and Nuclear Weapons AO Dissenting Opinion of Judge Weeramantry 484.

167 Nuclear Weapons AO Dissenting Opinion of Judge Shahabuddeen 408-409. See also Doswald-Beck 1997 IRRC 35-55.

168 In re Krupp, 15 Annual Digest of Public International Law Cases, 620 622. See also Nuclear Weapons AO Dissenting Opinion of Judge Shahabuddeen 407-408. 
Thus a weapon that is not covered by existing rules of international law may still be prohibited on the basis that such weapon was abhorrent to or per se contravened the dictates of public conscience and the principles of humanity. ${ }^{169}$

\section{CONCLUSION}

This Part having dealt with the introductory and legal aspects of weapons review processes, Part II of the series, which shall follow shortly, will deal with the more practical aspects of the process in question, scilicet the structure and composition of the review body and the various elements of the process of the review that need to be considered and regulated. Furthermore, the overall conclusion of the series will follow in Part 2.

169 See Coupland and Loye 60-65; Lawand et al 17; and Daoust et al June 200284 IRRC 351. See further St Petersburg Declaration. 